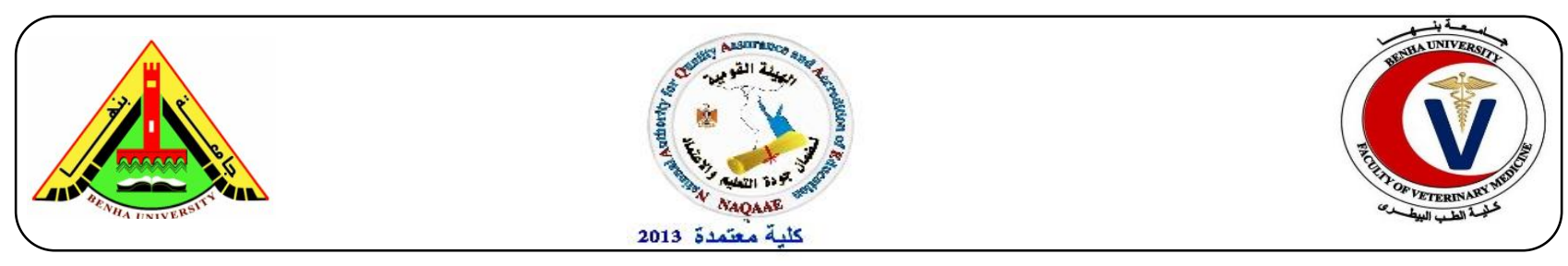

\title{
Biochemical evaluation of the combination of Pegylated IFN- $\alpha 2 b$ and Ribavarin therapy of Egyptian patients suffering from Hepatitis C Virus
}

\author{
Samy Ali Hussein"; Yakout Abd EL Fatah EL Senosi, Amira Ragab El Barky and Mohamed \\ Mahmoud Abdelkader Al Fakharany
}

Department of Biochemistry, Faculty of Vet. Med., Benha University, Egypt.

*Corresponding author: Samy Ali Hussein; email: samyaziza@yahoo.com.

\begin{abstract}
A B S T R A C T
The purpose of this study was to evaluate the biochemical parameters and cytokines levels in infected Egyptian patient. This study was conducted on 32 patients. 25 of them were suffering from chronic HCV and the other 7 males are selfreported healthy volunteers. They were classified as the following: Group I (control healthy group), Group II (HCV-non treated group) Group III- Group VI (HCV-treated with 12,24,36,48 ampoule of interferon). The obtained results showed a significant increase in the activities of serum liver marker enzymes ALT, AST and ALP, cytokines Il2, Il4 and Il10, also a significant increase was observed in serum Ferritin and Alpha feto protein. On the other hand, a significant decrease in both sera total protein and albumin level. Whereas administration of combination of Pegylated IFN- $\alpha 2 \mathrm{~b}$ and Ribavarin significantly improved the alert in the biochemical parameters. These results suggested that, combination therapy of both peg-interferon and ribavirin, emphasizing the influence of these compounds for patient with HCV, possibly preventing alteration of enzymes of liver activities. Because peg-interferon treatment can reduce liver injury and anti-inflammatory effect, as well as by decreasing plasma cytokine as cytokines, is present in patients with HCV liver disease. Furthermore, treatment with IFN- $\alpha$ diminishes the Th2 cytokine response. Thus, modulation of T- cell function and cytokine production may be one mechanism whereby IFN- $\alpha$ therapy results in reduced viral burden.
\end{abstract}

Keywords: Hepatitis C Virus; cytokines; TNF- $\alpha$; IgG and total protein.

(http://www.bvmj.bu.edu.eg)

(BVMJ-33(2): 9-16, DECEMBER, 2017)

\section{INTRODUCTION}

Hepatitis C Virus (HCV) infection is a major global health challenge; it is estimated that more than 80 million people are chronically infected worldwide, with 3-4 million new infections and 350000 deaths occurring each year because of HCV-related complications (Gower et al., 2014 and Kandeel et al., 2017). Hepatitis C virus (HCV) infection is a major public health burden in Egypt (Mohamoud et al., 2013). Egypt has the highest prevalence rate of $\mathrm{HCV}$ in the world (Sievert et al.,2011) and has high prevalence of hepatitis $\mathrm{C}$, resulting in high morbidity and mortality from liver disease. Approximately $12 \%$ of blood donors are seropositive for $\mathrm{HCV}$ antibodies (El-Zanaty and Way, 2008). The genotype distribution in Egypt is mainly genotype 4 (HCVG4) which is responsible for more than $90 \%$ of the infections, with the remaining due to HCV-G1(Abdel-Hamid et al., 2007). cytokines play in shaping many aspects of innate and adaptive immunity, there was a concerted effort toward identifying single nucleotide polymorphisms (SNPs) of cytokine associated with human diseases (O'Hara et al.,2012). cytokines such as IL-6, TNF-alpha (TNF- $\alpha$ ), TGF-beta (TGF- $\beta$ ) and growth factors play a significant role in the regeneration process conducted during chronic inflammation. Moreover, hepatotropic viruses are able to block the expression of chemokine receptors associated with cellular responses to avoid the migration of cells toward the liver. Thus, inhibiting chemokines and chemokines-receptors interactions may li- mit nonspecific cell migration and reduce inflammation during hepatotropic viral infections (Dustin et al., 2012). interferon alpha (IFN- $\alpha$ ) is the only cytokine currently used for the treatment of chronic viral hepatitis. Pegylated IFN- $\alpha$ combined with ribavirin leads to sustained viral clearance in $50 \%$ of patients with chronic hepatitis C (Heim, 2012). Ribavirin is a broadspectrum antiviral agent used as part of combination therapies for hepatitis C. This drug has immuno- modulating effects that induce type I 
cytokine production. Sustained viral load reductions with antiviral agents have also been observed to facilitate the recovery of specific $\mathrm{T}$ responses involving type I cytokine production in patients with hepatitis C (Hsu et al., 2012). Mechanistically, it has been suggested that IFN- $\alpha$ and Ribavirin treatment in HCV chronically infected patients up-regulates IL-10 and downregulates IL-2 and IL-12 to inhibit or reduce a cytolytic inflammatory response (Souvignet and Zarski, 2000). In comparison to single-drug therapy, the combination with IFN- $\alpha$ and Ribavirin also appears to restore the balance between the Th1 and Th2 cell populations more quickly and improve the efficiency of a cytolytic T-cell response in HCV-infected cells (Souvignet and Zarski, 2000). Accordingly, the purpose of the present study was to investigate the effect of the combination therapy of both interferon alpha and ribavirin on Egyptian patients suffering from HCV.

\section{MATERIALS AND METHODS}

\subsection{Subjects:}

This study was conducted on 32 patients. 25 of them were suffering from chronic $\mathrm{HCV}$ and the other 7 patients are self-reported, who were HCV, HBV and HIV antibody negative, serving as control. Subjects were $40-50$ years old, $80-100 \mathrm{~kg}$ body weight and no smokers. They were admitted from the Damanhur medical nation institute (DMNI). All individuals were subjected to full clinical examinations. The 25 patients HCVpatients were positive for $\mathrm{HCV}$ ab. and $\mathrm{HCV}$ RNA in serum and were negative for HBSAg.

\section{2. Experimental work:}

A total number of 32 patients individual were classified as the following:

Group I (control healthy group): comprised of 7 male clinically healthy individuals, received no drugs, served as control for all experimental groups.

Group II (HCV-non treated group): included 5 patients of patient suffering from $\mathrm{HCV}$, received no drugs.

Group III (HCV-treated with 12 ampoule of interferon): included 5 males patients that suffering from Chronic hepatitis $\mathrm{C}$ they received 12 weeks treatment with combination therapy, which was composed of pegylated IFN $\alpha 2 b$ administrated subcutaneously in a dose of 150 $\mathrm{ug} /$ week $(1.5 \mathrm{ug} / \mathrm{kg})$ according to body weight and $1000-1200 \mathrm{mg}$ of oral ribavirin USA200 mg
Capsules per day $(15 \mathrm{mg} / \mathrm{kg} / \mathrm{day})$ according to body weight (two Capsules three time daily)

Group IV (HCV-treated with 24 ampoule of interferon): included 5 males patients that suffering from Chronic hepatitis $\mathrm{C}$ they received 24 weeks treatment with combination therapy, which was composed of pegylated IFN $\alpha 2 b$ administrated subcutaneously in a dose of 150 ug/week (1.5ug/kg) according to body weight and $1000-1200 \mathrm{mg}$ of oral ribavirin USA200 mg Capsules per day $(15 \mathrm{mg} / \mathrm{kg} /$ day $)$ according to body weight (two Capsules three time daily)

Group V (HCV-treated with 36 ampoule of interferon): included 5 males patients that suffering from Chronic hepatitis $\mathrm{C}$ they received 36 weeks treatment with combination therapy, which was composed of pegylated IFN $\alpha 2 b$ administrated subcutaneously in a dose of 150 ug/week $(1.5 \mathrm{ug} / \mathrm{kg})$ according to body weight and $1000-1200 \mathrm{mg}$ of oral ribavirin USA200 mg Capsules per day $(15 \mathrm{mg} / \mathrm{kg} /$ day $)$ according to body weight (two Capsules three time daily)

Group VI (HCV-treated with 48 ampoule of interferon): included 5 males patients that suffering from Chronic hepatitis $\mathrm{C}$ they received 48 weeks treatment with combination therapy, which was composed of pegylated IFN $a 2 b$ administrated subcutaneously in a dose of 150 ug/week (1.5ug/kg) according to body weight and $1000-1200 \mathrm{mg}$ of oral ribavirin USA200 mg Capsules per day $(15 \mathrm{mg} / \mathrm{kg} /$ day $)$ according to body weight (two Capsules three time daily)

\section{3. Sampling:}

Fasting blood samples for plasma and serum separations were collected from madian cubital vein at the end of each experimental period and after overnight fasting in dry, clean and screw capped plain and EDTA tubes, plasma and serum were separated by centrifugation at 2500 r.p.m. for 15 minutes. The clean, clear plasma and serum was seprated by auomatic pipette and received in dry sterile sample tube, then kept in a deep freez at $20^{\circ} \mathrm{c}$ until used for subsequent biochemical analysis.

\subsection{Biochemical analysis}

Serum ALT, AST and ALP, were determined according to the method described by Breuer, 1996 and Belfield and Goldberg, 1971), Plasma IL-2 was determined by using Human IL-2 ELISA Kit (Thermoscientific, USA), The level of IL-4 in the plasma was determined according to the method described by Banchereau, (1990) by using ELISA kit, TNF- $\alpha$ according to the method described by Tian et al. (2005), Serum total protein concentration according to the method 
described by (Young, 2001), Serum albumin was determined colorimetrically according to the method described by (Young, 2001), serum $\alpha$ fetoprotein, ferritin and $\mathrm{IgG}$ was determined by using Human ELISA Kit.

\section{5. Statistical analysis:}

The obtained data were statistically analyzed by one-way analysis of variance (ANOVA)

followed by the Duncan multiple test. All analyses were performed using the statistical package for social science (SPSS, 13.0 software, 2009). Values of $P<0.05$ were considered to be significant.

\section{RESULTS}

3. RESULTS

Table 1: Effect of the treatment with both pegylated IFN- $\alpha 2 b$ and ribavarin in patient suffering from hepatitis $\mathrm{C}$

\begin{tabular}{lllllll}
\hline parameter & G.I & G.II & G.III & G.IV & G.V & G.VI \\
\hline $\begin{array}{l}\text { Serum ALT } \\
\text { activities (U/L) }\end{array}$ & $20.29 \pm 1.98^{\mathrm{c}}$ & $76.8 \pm 7.57^{\mathrm{a}}$ & $45.2 \pm 6.85^{\mathrm{b}}$ & $33.2 \pm 5.04^{\mathrm{bc}}$ & $42.0 \pm 4.35^{\mathrm{b}}$ & $40.8 \pm 2.20^{\mathrm{b}}$ \\
$\begin{array}{l}\text { Serum AST } \\
\text { activities (U/L) }\end{array}$ & $20.29 \pm 1.27^{\mathrm{c}}$ & $72.6 \pm 9.97^{\mathrm{a}}$ & $40.4 \pm 5.2^{\mathrm{b}}$ & $35.5 \pm 7.39^{\mathrm{bc}}$ & $40.2 \pm 4.12^{\mathrm{b}}$ & $40.8 \pm 3.26^{\mathrm{b}}$ \\
$\begin{array}{l}\text { Serum ALP } \\
\text { activities(U/L) }\end{array}$ & $117.71 \pm 11.487^{\mathrm{b}}$ & $165.60 \pm 22.85^{\mathrm{a}}$ & $111.80 \pm 6.46^{\mathrm{b}}$ & $110.00 \pm 6.88^{\mathrm{b}}$ & $115.00 \pm 8.25^{\mathrm{b}}$ & $111.60 \pm 6.19^{\mathrm{b}}$ \\
$\begin{array}{l}\text { Serum GGT } \\
\text { activities (U/L) }\end{array}$ & $21.86 \pm 2.0^{\mathrm{b}}$ & $39.00 \pm 5.99^{\mathrm{a}}$ & $22.20 \pm 3.37^{\mathrm{b}}$ & $27.80 \pm 2.56^{\mathrm{b}}$ & $18.60 \pm 4.15^{\mathrm{b}}$ & $21.20 \pm 3.15^{\mathrm{b}}$ \\
$\begin{array}{l}\text { Plasma IL-2 level } \\
\text { (pg/ml) }\end{array}$ & $5.66 \pm 0.71^{\mathrm{d}}$ & $17.14 \pm 1.9^{\mathrm{a}}$ & $8.96 \pm 0.84^{\mathrm{bc}}$ & $9.90 \pm 0.89^{\mathrm{b}}$ & $5.20 \pm 0.36^{\mathrm{d}}$ & $6.22 \pm 0.69^{\mathrm{dc}}$ \\
$\begin{array}{l}\text { Plasma IL-4 level } \\
\text { (pg/ml) }\end{array}$ & $4.97 \pm 0.28^{\mathrm{d}}$ & $20.22 \pm 2.66^{\mathrm{a}}$ & $9.98 \pm 1.08^{\mathrm{bc}}$ & $11.41 \pm 1.07^{\mathrm{b}}$ & $9.10 \pm 0.51^{\mathrm{bc}}$ & $6.94 \pm 0.74^{\mathrm{dc}}$ \\
$\begin{array}{l}\text { Plasma IL-10 level } \\
(\mathrm{pg} / \mathrm{ml})\end{array}$ & $7.37 \pm 0.55^{\mathrm{d}}$ & $61.20 \pm 7.74^{\mathrm{a}}$ & $17.20 \pm 1.57^{\mathrm{c}}$ & $29.22 \pm 0.42^{\mathrm{b}}$ & $15.30 \pm 1.96^{\mathrm{cd}}$ & $6.34 \pm 0.38^{\mathrm{d}}$ \\
\hline
\end{tabular}

Data are presented as (Mean \pm S.E). S.E $=$ Standard error. Mean values with different superscript letters in the same row are significantly different at $(P<0.05)$. Group I: control, group II: HCV-non treated group, Group III (HCV-treated with 12 ampoule of interferon), Group IV (HCV-treated with 24 ampoule of interferon), Group V (HCV-treated with 36 ampoule of interferon) and Group VI (HCV-treated with 48 ampoule of interferon).

Table 2: Effect of the treatment with both pegylated IFN- $\alpha 2 b$ and ribavarin in patient suffering from hepatitis $\mathrm{C}$

\begin{tabular}{|c|c|c|c|c|c|c|}
\hline parameter & G.I & G.II & G.III & G.IV & G.V & G.VI \\
\hline Plasma & & & & & & \\
\hline $\begin{array}{l}\text { TNF- } \alpha \\
\text { level } \\
(\mathrm{pg} / \mathrm{ml})\end{array}$ & $4.64 \pm 0.34^{\mathrm{e}}$ & $13.10 \pm 0.77^{\mathrm{c}}$ & $18.30 \pm 0.84^{\mathrm{ac}}$ & $19.42 \pm 1.10^{\mathrm{a}}$ & $16.29 \pm 1.25^{\mathrm{b}}$ & $9.02 \pm 0.65^{\mathrm{d}}$ \\
\hline $\begin{array}{l}\text { serum } \\
\text { total } \\
\text { protein } \\
(\mathrm{g} / \mathrm{dl})\end{array}$ & $8.34 \pm 0.05^{\mathrm{a}}$ & $6.86 \pm 0.19^{c}$ & $7.82 \pm 0.19^{\mathrm{ab}}$ & $8.22 \pm 0.19^{\mathrm{a}}$ & $7.50 \pm 0.25^{\mathrm{b}}$ & $7.80 \pm 0.20^{\mathrm{ab}}$ \\
\hline $\begin{array}{l}\text { serum } \\
\text { albumin } \\
(\mathrm{g} / \mathrm{dl})\end{array}$ & $5.09 \pm 0.07^{\mathrm{a}}$ & $3.12 \pm 0.20^{\mathrm{c}}$ & $3.88 \pm 0.21^{\mathrm{b}}$ & $4.02 \pm 0.12^{\mathrm{b}}$ & $3.68 \pm 0.06^{\mathrm{b}}$ & $4.16 \pm 0.24^{\mathrm{b}}$ \\
\hline $\begin{array}{l}\text { Serum } \alpha- \\
\operatorname{FP}(\mathrm{ng} / \mathrm{ml} \\
)\end{array}$ & $4.33 \pm 0.42^{\mathrm{b}}$ & $6.46 \pm 0.5^{\mathrm{a}}$ & $4.32 \pm 0.66^{\mathrm{b}}$ & $3.86 \pm 0.55^{\mathrm{b}}$ & $3.78 \pm 0.75^{\mathrm{b}}$ & $4.32 \pm 0.51^{\mathrm{b}}$ \\
\hline $\begin{array}{l}\text { Serum } \\
\text { Ferritin } \\
(\mathrm{ng} / \mathrm{ml})\end{array}$ & $135.29 \pm 6.52^{\mathrm{d}}$ & $212.00 \pm 9.10^{\mathrm{a}}$ & $186.20 \pm 5.27^{\mathrm{b}}$ & $163.60 \pm 13.20^{\mathrm{bc}}$ & $170.60 \pm 9.52^{\mathrm{bc}}$ & $157.40 \pm 7.20^{\mathrm{cd}}$ \\
\hline Serum & $1313.60 \pm 41.81^{\mathrm{b}}$ & $1239.80 \pm 31.33$ & $1040.00 \pm 69.88$ & $1622.00 \pm 41.52$ & $1362.20 \pm 29.29^{\mathrm{b}}$ & $1411.80 \pm 49.82$ \\
\hline
\end{tabular}


same row are significantly different at $(P<0.05)$. Group I: control, group II: HCV-non treated group, Group III (HCV-treated with 12 ampoule of interferon), Group IV (HCV-treated with 24 ampoule of interferon), Group V (HCV-treated with 36 ampoule of interferon) and Group VI (HCV-treated with 48 ampoule of interferon).

\section{DISCUSSION}

The obtained data presented in table (1) revealed that, A significant increase in both sera ALT, AST and ALP activities were observed in HCV-non treated group (G. II) when compared with the control healthy individual (G. I). whereas the treatment with pegylated IFN- $\alpha 2 b$ and ribavarin significantly reduced the elevated serum ALT, AST and ALP activities in patient that treated with 12, 24, 36 and 48 ampoule (G. IIIG.VI) as compared to HCV-non treated group (G. II). Also, Plasma IL-2, IL-4, IL-10 and TNF- $\alpha$ showed a significant increase in patient with HCV-non treated group (G. II) as compared to the control healthy individual group (G. I), whereas treatment with pegylated IFN- $\alpha 2 b$ and ribavarin significantly reduced elevated Plasma, IL-2, IL-4, IL-10 and TNF- $\alpha$ in HCV-treated group (G. IIIG.VI) as compared to HCV-non treated group (G. II). On the other hand, a significant decrease was observed in serum total protein and albumin level in patient with $\mathrm{HCV}$-non treated group (G. II) as compared to the control healthy individual group (G. I). Meanwhile the treatment with pegylated IFN- $\alpha 2 b$ and ribavarin resulted in a significant increase in both sera total protein and albumin levels in patient treated with 12, 24, 36 and 48 ampoule group (G. III - G.VI) as compared to $\mathrm{HCV}$-non treated group.

The obtained data presented in table (2) revealed that, A significant increase was observed in serum $\alpha$-fetoprotein, Ferritin level in patient with HCV-non treated group (G. II) as compared to the control healthy individual group (G. I). On the other hand, A non significant decrease was observed in serum IgG level in patient with HCVnon treated group (G. II) as compared to the control healthy individual group (G. I).Treatment with pegylated IFN- $\alpha 2 b$ and ribavarin resulted in a significant decrease in serum $\alpha$-fetoprotein and Ferritin levels in patient that treated with 12, 24, 36 and 48 ampoule group (G. III - G.VI) as compared to HCV-non treated group. Meanwhile, a significant decrease in serum $\operatorname{IgG}$ levels in patient that treated with 12 ampoule (G. III) was observed. In contrast, patient with $\mathrm{HCV}$ that treated with 24, 36 and 48 ampoule group (G. IV -
G.VI) showed a significant increase in serum $\mathrm{IgG}$ levels as compared to $\mathrm{HCV}$-non treated group.

Hepatitis $\mathrm{C}$ is a global public health problem where about 130 to 150 million people suffer from chronic HCV (WHO, 2015). It is estimated that $\mathrm{HCV}$ related deaths are 350,000 to 500,000 annually. Egypt has the highest prevalence of hepatitis $\mathrm{C}$ virus (HCV) in the world (Mohamoud et al., 2013). HCV is considered the leading cause of chronic hepatitis, liver cirrhosis and hepatocellular carcinoma (HCC). About 55\%$85 \%$ of $\mathrm{HCV}$ infected cases become chronic active cases and pass through the way of developing fibrosis, cirrhosis, and may progress till become decompensated cirrhosis and HCC ('WHO | Hepatitis C', 2015). This makes HCV infection and its complications are among the leading public health challenges in Egypt (Miller and Abu-Raddad, 2010; Mohamoud et al., 2013).

The recorded data demonstrated in (Table1) resulted in, a significant increase in serum ALT, AST and Alk. Phosphatase activities were observed in hepatitis $\mathrm{C}$ non treated group (G. II) when compared to the control normal group (G. I). The obtained data are nearly similar to those reported by Nadeem et al. (2010) who reported that Patients of chronic hepatitis $\mathrm{C}$ had raised serum alanine aminotransferase and levels with the mean baseline level of $93 \mathrm{IU} / \mathrm{L}$ with a range of 13-383 IU/L. Serum aspartate aminotransferase levels were also elevated with mean baseline level of $59.65 \mathrm{IU} / \mathrm{L}$ ranging from $18-370 \mathrm{IU} / \mathrm{L}$. Serum ALT and S. AST are used to follow-up the patients already treated to rule out relapse of the disease (Nadeem et al., 2010). Elevated aminotransferase levels may suggest acute viral hepatitis or toxic or ischemic liver injury. Furthermore, this biochemical picture can be the presenting feature of autoimmune hepatitis (Kessler et al., 2004). Also, Afify et al. (2016) demonstrated that, the levels of serum ALT, AST, and ALP were significantly higher in positive HCV-infected patient's compared with negative $\mathrm{HCV}$ patients, whereas GGT was not significantly increased. Elevation of ALP is observed in patients who have some form of extra hepatic and intra hepatic bile duct obstruction. The AST enzymes used for many biochemical 
reactions in the living cell. Elevation of this enzymes in the blood is therefore an indication of tissue damage and altered membrane permeability (Alzubaide et al., 2015).

Treatment with interferon and Ribavirin to patient with hepatitis $\mathrm{C}$ significantly reduced plasma ALT , AST and Alk. Phosphatase in (G. III-G.VI) as compared to HCV-non treated group (G. II). Serum alanine aminotransferase (ALT) levels is an important marker for the management of chronic hepatitis C. Our results were in accordance to Mohammed et al. (2012) who stated that serum ALT levels in the patients with chronic hepatitis $\mathrm{C}$ after treatment with Interferon Alpha 2b (3 million units once per week for 24 weeks) and ribavirin $(10 \mathrm{mg} / \mathrm{kg} / \mathrm{day})$ with the average dose ranging from 800 to $1000 \mathrm{mg} /$ day was statistically significant decrease $(p<0.05)$ when compared to its level before treatment, this approve that the treatment reduce liver injury because serum ALT levels generally reflect liver injury Toson et al., (2014).

The obtained results demonstrated in (Tables 1) revealed that a significant increase in serum IL2, IL-4, IL-10 and TNF- $\alpha$ was observed in HVCpatient hepatitis $\mathrm{C}$ (G. II) as compared to normal health individual (G. I). IL-10 has been reported to be one of the potential factors in establishing immune suppression and viral persistence (Ha et al., 2008). The pronounced increase in sera IL-10 was in accordance to El-Emshaty et al. (2015) they reported that both IL-10 and IL-12 were elevated significantly in the sera of patients with HCV infection as compared to non disease control group and the level was elevated significantly among disease groups. Cytokines play an important role in viral clearance, infection control, inflammation, regeneration, and fibrosis and also are implicated in the pathological processes occurring in the liver during viral infection (Costantini et al., 2010).

The striking elevation of pro-inflammatory cytokine TNF- $\alpha$ in asymptomatic HCV carriers may reflect both insufficiency of HCV elimination and a failure to control the cytokine cascade (Zekri et al., 2005). Treatment with both pegylated interferon-alpha and ribavirin to $\mathrm{HCV}$ Egyptian patient (G.III-G.VI) significantly decrease serum cytokines. Combination therapy of both IFN $\beta$ and ribavirin treatment has an overall response rate of only about $40-60 \%$. Successful treatment reduces T2 cytokine levels (e.g. IL-4 and IL-10) in serum so IFN $\alpha$ probably promotes a $\mathrm{T} 1$ cytokine response in addition to its direct antiviral effects (Cacciarelli et al. 1996). High pretreatment serum HCV RNA levels and $\mathrm{HCV}$ genotype $1 \mathrm{~b}$ decrease the probability of sustained biochemical or virological response (McHutchison et al., 1999). Treatment with IFN-a diminishes the Th2 cytokine response. Thus, modulation of T-cell function and cytokine production may be one mechanism whereby IFN$\alpha$ therapy results in reduced viral burden (Cacciarelli et al., 1996). The obtained results demonstrated in (Table 1) showed that a significant decrease was observed in HCV patient non treated group (G. II) as compared to normal healthy individuals (G. I). The obtained data were in accordance to Jacobson et al. (2010) who reported that albumin and platelets gradually decrease with HCV infection disease progression.

Protein and albumin determinations are frequently included in the routine laboratory evaluation of $\mathrm{HCV}$-infected patients. Albumin comprises $45-55 \%$ of the total serum protein. $\mathrm{HCV}$ hepatitis is an acute to chronic inflammation of hepatocytes, which may develop into liver cirrhosis. The levels of serum albumin were significantly decreased in patients with $\mathrm{HCV}$ hepatic cirrhosis as compared to the control group (Abou-El-Makarem et al., 2104). In humans, albumin synthesis takes place only in the liver. Albumin is not stored by the liver but is secreted into the portal circulation as soon as it is manufactured. Under physiological conditions, albumin may have significant antioxidant potential. This may be related to the abundance of sulfhydryl (- $\mathrm{SH}$ ) groups on the albumin molecule (Nicholson et al., 2000). A decrease in serum levels of albumin, may suggest decreased hepatic production due to decreased liver function following hepatocellular disease (D'Agata and Balistreri, 1999).

Treatment with both pegylated interferonalpha and ribavirin to HCV Egyptian patient (G.III-G.VI) significantly increase serum total protein and serum albumin levels as compared to HCV-non treated group (G. II). the obtained data within agreement with (Alzubaide et al., 2015) they stated that, treatment with interferon alfa for 12 and 24 weeks cause significant increase $(\mathrm{P}<$ 0.001) in Blood sugar and Albumin levels and significant decrease in Blood urea, serum creatinine direct and indirect and total bilirubin in $\mathrm{HCV}$ patients as compare to normal individuals (control). Ribavirin acts on HCV-related glomerular or liver lesions through a mechanism other than a reduction in viral replication. One possibility is an immunomodulating effect (Di martino et al., 1997). The obtained results demonstrated in (Table 2), showed that a 
significant increase in serum ferritin, alpha feto protein and $\mathrm{IgG}$ was observed in hepatitis $\mathrm{C}$ non treated group (G. II) as compared to control normal individual group (G. I).

Alpha fetoprotein is a surrogate marker for hepatocellular carcinoma (HCC) but is insensitive and very nonspecific. The obtained data were in accordance to El-Shahat et al. (2012) who reported that AFP was significantly high in both HCV groups, this increase was more pronounced in the group with high HCV titer as compared to healthy volunteers. AFP is considered as specific biomarker for liver cirrhosis and it is synthesized mainly in the fetal stage; practically no production of this marker occurs in the normal adult. However, when some adult cells are transformed to cancer cells, the synthesis of AFP commences again, a significant positive correlation between (AFP) and hepatitis $\mathrm{C}$ virus and confirmed the results recently reported by Abdel-Wahhab et al. (2011).

Treatment with both pegylated interferonalpha and ribavirin to HCV Egyptian patient (G.III-G.VI) significantly reduced elevated serum AFP levels as compared to HCV-non treated group (G. II).The obtained data were in agreement with Şenol et al. (2016) they stated that the patients with chronic hepatitis $\mathrm{C}$, after treatment with interferon- $\alpha$ and ribavirin, Mean serum AFP levels gradually decreased from pretreatment level of $6,6 \pm 6,05 \mathrm{ng} / \mathrm{ml}$ to $5,1 \pm 3,7$ (p>0,05), to 4,34 $\pm 4,64(\mathrm{p}>0,05)$ and to $2,63 \pm 2,17(\mathrm{p}<0,001)$ at month 3,6 and 12 of the therapy, respectively. Although AFP decrease at month 3 was non significant, a significant decrease of mean serum AFP levels after 6 and 12 months of therapy was demonstrated in the patients with high AFP $(>10$ $\mathrm{ng} / \mathrm{ml}$ ), therapy with IFN may reduce the rate of hepatocyte replication, regardless of its antiinflammatory action.

Serum iron markers especially ferritin and transferrin might be used as surrogate markers for both liver fibrosis and necroinflammatory activity (Vagu et al. 2013). Patients with chronic hepatitis $\mathrm{C}$ (CHC) often have elevated serum iron markers, which may worsen liver injury (Poddar, 2017). The obtained data were in agreement with Afia et al., (2015) who reported that, Patients with elevated ALT and AST had significantly higher mean serum ferritin than those with normal ALT and AST.

Treatment with both pegylated interferonalpha and ribavirin to HCV Egyptian patient (G.III-G.VI) significantly reduced elevated serum ferritin levels as compared to HCV-non treated group (G. II). The reduction of hepatic iron content following response to interferon (IFN) therapy suggest that hepatic iron overload is the result of hepatocyte necrosis, which leads to release of ferritin from hepatocytes and subsequent uptake by macrophages (Kaito, 2007). However, another possible mechanism to explain the elevated iron stores could be the increased intestinal iron absorption. Indeed, recent investigations have found decreased levels of hepcidin (a peptide hormone produced in the liver that has an inhibitory effect on iron absorption) and increased levels of transferrin receptor 2 (which is located on the hepatocyte membrane and is involved in the uptake of iron by hepatocytes) in chronic HCV infection (Kageyama et al., 2000).

Cryoglobulinemia is defined as the presence of immunoglobulins in serum which reversibly precipitate in vitro at low temperatures. Hepatitis $\mathrm{C}$ is most commonly associated with mixed Cryoglobulinemia (MC), which can be classified as type II in which the precipitates contain polyclonal $\operatorname{IgG}$ and monoclonal IgM with antigamma globulin (rheumatoid factor activity) or Type III MC in which precipitates are composed of polyclonal IgG and polyclonal IgM (Agnello, 2000).

Treatment with both pegylated interferonalpha and ribavirin to HCV Egyptian patient (G.III) showed a significant decrease as compared to(G. II). On the other hand a significant increase was observed in (G. IV-G. VI) as compared to HCV-non treated group (G. II). The obtained data are nearly similar to Musset et al. (1997) they stated that a significant decrease in IgGl levels was observed after 6 months of therapy. Posttherapy decrease in serum IgGl levels was observed in eight of the 11 patients who had high serum IgGl prior to treatment and in two of four patients with initially normal IgGl levels. Although the difference is not statistically significant. this might suggest that IFN- $\alpha$ (therapy mainly normalized abnormally high IgGl levels rather than normal values. IFN- $\alpha$ might modify serum IgG levels by affecting their production either directly or through a cytokine cascade than indirectly by its effect on the viral infection (Musset et al., 1997). Moreover the biologic effects of various $1 F N$ are quite heterogenous and IFN has been shown to inhibit cell growth, to activate natural killer cells and to affect leukocyte migration. It has also been demonstrated a modulating effect of IFN on B cell functions, particularly measured as immunoglobulin $\mathrm{IgG}$ 
production in vivo and in vitro (Gattoni, et al., 2006).

\section{CONCLUSION \& RECOMMENDATIONS}

In conclusion, the present study demonstrated that HCV-hepatitis patient caused a significant increase in the activities of serum ALT, AST and ALP. In addition to, a significant increase in plasma IL-2, IL-4, IL-10 and TNF- $\alpha$ were observed in patient suffering from HCV. Also, this study demonstrated that, there was significant decrease in both sera total protein and albumin levels. Meanwhile, a significant increase of serum AFP, ferritin and IgG. The findings of the present study demonstrated that treatment of interferon and ribravarine provided an effective treatment against complication which raised due to virus $\mathrm{C}$, since this compound was able to ameliorate serum biochemical parameters, enzymatic and cytokine profile. These results may contribute to a better understanding of the role of both peg-interferon and ribavirin therapy, emphasizing the influence of these compounds for patient with $\mathrm{HCV}$, possibly preventing alteration of enzymes of liver activities. Because peginterferon treatment can reduce liver injury and anti-inflammatory effect, as well as by decreasing plasma cytokine as cytokines, is present in patients with $\mathrm{HCV}$ liver disease. So we recommended that, administration of both peginterferon and ribavirin is very important for treating and protecting of liver tissue, against inflammation.

\section{REFERENCES}

Abdel-Hamid, M.; El-Daly, M.; Molnegren, V.; El-Kafrawy, S.; Abdel-Latif, S.; Esmat, G. and et al. (2007). Genetic diversity in hepatitis C virus in Egypt and possible association with hepatocellular carcinoma. $\mathrm{J}$ Gen Virol; 88:1526-31.

Abdel-Wahhab, M.A.; Gamil, K.; El-Kady, A.A.; El-Nekeety A.A. and K.M. Naguib, (2011): Therapeutic effects of Korean red ginseng extract in Egyptian patients with chronic liver diseases. J. Ginseng Res., 35(1): 6979.

Abou-El-Makarem, M. M.; Moustafa , M, M,; M.A. Fahmy, ; Abdel-Hamed, A. M.; Elfayomy K. N. and Darwish, M. M.A. (2014): Evaluation of Carbonylated Proteins in Hepatitis C Virus Patients. Mod Chem, 2:2.
Afia,A. A.; Halbus, W.R.; Hassan, M. A.; Ramadan, A. M. and Fouda, M. M. I. (2015): Relationship between elevated liver enzymes with iron overload and viral hepatitis in children withb-thalassemia major. AL-AZHAR ASSIUT MEDICAL JOURNAL. VOL 13, NO 2, pp.93-97.

Afify,M.; Hamza,A. H. and Alomari, R.A. (2016): Correlation Between Serum Cytokines, Interferons, and Liver Functions in Hepatitis C Virus Patients. JOURNAL OF INTERFERON \& CYTOKINE RESEARCH.7 pages.

Agnello,V. (2000): "Mixed cryoglobulinemia and other extrahepatic manifestations of $\mathrm{HCV}$ infection," in Hepatitis C, T. J. Liang and J. H. Hoofnagle, Eds., pp. 295-313, Academic Press, San Diego, Calif, USA, View at Google Scholar.

Alzubaide,B.A .; Yousif,J.J. and Almaory R. T. (2015): Effects of treatment with Interferon alfa on some biochemical indices among hepatitis C patients. Journal of Kerbala University, Vol. 13 No.1 Scientificpp. 115122.

Banchereau, J. (1990) Interleukin-4. Médecine /Science 6:946-953.

Breuer, j. (1996): Report on the symposium "drug effect in clinical chemistry methods. Eur $\mathbf{J}$ Clin Chem clin Biochem. 34; 385-386.

Cacciarelli, T.V.; Martinez, O.M.; Gish, R.G.; Villanueva, J.C.and Krams, S.M. (1996): Immunoregulatory cytokines in chronic hepatitis $\mathrm{C}$ virus infection: pre- and post treatment with interferon alfa. Hepatology; 24: 6-9

Costantini, S.; Capone, F.; Guerriero, E.; Maio, P.; Colonna, G. and Castello, G. (2010) "Serum cytokine levels as putative prognostic markers in the progression of chronic HCV hepatitis to cirrhosis," European Cytokine Network, vol. 21, no. 4, pp. 251-256, 2010.

D'Agata,I. D. and Balistreri W. F. (1999): Evaluation of Liver Disease in the Pediatric Patient. Pediatrics in Review Vol. 20 No. 1. Pp. 376-389.

Di martino, V.; SAURINI, F.; SAMUEL, D.; GIGOU, M.; DUSSAIX, E.; REYNES, M.; BISMUTH, H. and FERAY, C: (1997): Long term longitudinal study of intrahepatic hepatitis $\mathrm{C}$ virus replication after liver transplantation. Hepatology 26:1343-1350,

Dustin, L.B. and Charles, E.D. (2012): Primary, post- primary and non-specific immunoglobulin $\mathrm{M}$ responses in $\mathrm{HCV}$ 
infection. Antiviral Therapy, 17, 14491452.

El-Emshaty, H.M.; Nasif, W. A. and Mohamed, I.E. (2015): Serum Cytokine of IL-10 and IL-12 in Chronic Liver Disease: The Immune and Inflammatory Response. Disease markers. Volume 2015. 7 pages

El-Shahat, E. A.; Swelim,M. A.; Mohamed, A. F. and Abdel-Wahhab, M. A. (2012) : Correlation Study Between Aflatoxin M1 and Hepatitis C Virus in Egyptian Patients with Chronic Liver Disease. World Journal of Medical Sciences 7 (4): 224-231.

El-Zanaty, F. and Way A. (2008) Egypt Demographic and Health Survey, Cairo, Egypt: Ministry of Health and Population, 2009; 2009. Demographic and Health Survey (EDHS).

Gattoni, A., et al. (2006): Interferon-gamma: biologic functions and HCV terapy (type I/II) (2 of 2 parts). Clin Ter, 157: 457-68.

Gower, E.; Estes, C.; Blach, S.; Razavi-Shearer, K. and Razavi, H. (2014): Global epidemiology and genotype distribution of the hepatitis C virus infection. J Hepatol; 61: S45-57.

Heim, M.H. (2012): Interferons and hepatitis C virus. Swiss Medical Weekly, 142, w13586.

Jacobson, I. M. (2001): Managing Chronic Hepatitis C Virus Infection. Hospital Physician. p p. $34-41$

Kageyama, F.; Kobayashi, Y.; Kawasaki, T.; Toyokuni, S.; Uchida, K. and Nakamura, H. (2000): Successful interferon therapy reverses enhanced hepatic iron accumulation and lipid peroxidation in chronic hepatitis C. Am J Gastroenterol; 95:1041-1050.

Kaito, M. (2007): Molecular mechanism of iron metabolism and overload in chronic hepatitis C. J Gastroenterol;42:96-99.

Kandeel,A.; Genedy,M.; El-Refai,S.; Funk, A. Fontanet, L.;A. and Talaat,M. (2017): The prevalence of hepatitis $C$ virus infection in Egypt 2015: implications for future policy on prevention and treatment. Liver Int. 2017; 37: 45-53.

Mahmood Z; Abdul Shakoor and Riaz, M. (2013): Investigation of Selective Biochemical Markers from Chronic Hepatitis C Patients in Relation to Environmental Pollutants. World Applied Sciences Journal 24 (8): 1084-1090.

Miller, F.D. and Abu-Raddad, L.J. (2010): Evidence of intense ongoing endemic transmission of hepatitis $\mathrm{C}$ virus in Egypt.
Proc Natl Acad Sci USA, 107(33):1475714762.

Mohamed, A.A.; Loutfy, S.A.; Craik, J.D.; Hashem, A.M. and Sia, I. (2011) Chronic hepatitis C genotype-4 infection: role of insulin resistance in hepatocellular carcinoma, Virology Journal, 8:496. doi:10.1186/1743 -422X-8-496.

Mohamoud,Y. A.; Mumtaz, G.R.; Riome,S.; D. M. Laith, and Abu-Raddad, J. (2013): The epidemiology of hepatitis $\mathrm{C}$ virus in Egypt: a systematic review and data synthesis. BMC Infectious Diseases. 13:288.

Musset, L.; Ghillani, P.; Lunel, F.; Cacoub, P.; Cresta, P.; Frangeulb, L.; Rosenheim M., and Preud, J. (1997): Variations of serum IgG subclass levels in hepatitis $\mathrm{C}$ virus infection during interferon-a therapy. Immunology Letters 55 (1997) 4145.

Nicholson, J.P.; Wolmarans, M.R. and Park, G.R. (2000) The role of albumin in critical illness. Br J Anaesth 85: 599-610.

Nicholson, J.P.; Wolmarans, M.R. and Park, G.R. (2000) The role of albumin in critical illness. Br J Anaesth 85: 599-610.I

O'Hara, H.A.; Silver, J.S. and Hunter, C.A. (2012): The immunology of IL-27. Advances in Immunology. Adv Immunol, 115:1-44.

Poddar S. (2017): Hepatitis C and Iron Over Load. Malaysian Journal of Medical Research | Vol. 1 (1). Pp. 25-30.

Sievert, W.; Altraif, I.; Razavi, H.A.; Abdo, A.; Ahmed, E.A.; Alomair, A. et al. (2011) A systematic review of hepatitis $\mathrm{C}$ virus epidemiology in Asia, Australia and Egypt. Liver Int;31(Suppl. 2):61-80.

Souvignet, C. and Zarski, J.P. (2000): Combination treatment for chronic hepatitis $\mathrm{C}$ : what is the role of ribavirin? Fundam. Clin. Pharmacol. 14,321-325.

Tian, B.; Nowak, D.E.; Jamaluddin, M.; Wang, S. and Brasier, A. R. (2005): Identification of direct genomic targets downstream of the nuclear factor-kappaB transcription factor mediating tumor necrosis factor signaling. $\mathbf{J}$ Biol Chem.; 280 (17):17435-48.

Toson, E. A.; EL-Bendary, M.M.; El-mezayen, H. A. and Sahyon, H. A. (2014): Longitudinal Evaluation of Hyaluronic Acid and Its Degrading Enzymes and Degradation Products in Egyptian Patients with Chronic Hepatitis C Treated By Pegylated Interferon and Ribavirin. International Conference on Advances in Agricultural, Biological \& Environmental Sciences 
WHO (2015, July). Hepatitis C Fact Sheet. Retrieved 25 December 2015, from Mohammed,M. A. ; Abd Elmaksoud, M. D.; Abd El Maksoud, N. ; El-Mezayen H. A.; El-Garaam H. (2012): Serum levels of trace elements in Egyptian patients with chronic hepatitis $\mathrm{C}$ under interferon therapy. Journal of Genetic Engineering and Biotechnology (2012) 10, 81-86.

Young, D. S. (2001): Effect of disease on clinical lab. Tests, 4 th Ed AACC.

Zekri, A. N.; El-Din Ashour, M. S.; Hassan A.; Alam El-Din H. M; El-Shehaby A.M.R and Abu-Shady M. A. (2005): TNFCytokine profile in Egyptian hepatitis $\mathrm{C}$ virus genotype-4 in relation to liver disease progression. World $\mathrm{J}$ Gastroenterol 2005; 11(42):6624-6630

Zekri, A. R. N.; Ashour, M. S. E.; Hassan,A.; ElDin,H. M. A.; El-Shehaby, A. M. R. and Abu-Shady M. A., (2005) "Cytokine proÖle in Egyptian hepatitis $\mathrm{C}$ virus genotype-4 in relation to liver disease progression," World Journal of Gastroenterology, vol. 11, no. 42, pp. 6624-6630,

Zekri, A.N.; Alam El-Din, H. M.; Bahnassy,A. A.; El-Shehabi, A.M.R.; El-Leethy,H.; Omar, A. and Khaled, H.M. (2005) : Trugene Sequencing Versus INNO-LiPA for SubGenotyping of HCV Genotype-4. J. Med. Virol. 75: 412-420.

Zekri, A.N.; Ashour, M. S.; Hassan, A.; Alam ElDin, H. M.; El-Shehaby, A. M.R and AbuShady, M. A. (2005): Cytokine profile in Egyptian Hepatitis C virus genotype-4 in relation to liver disease progression. World J Gastroenterol November 14, 2005 Volume 11 Number 42. 